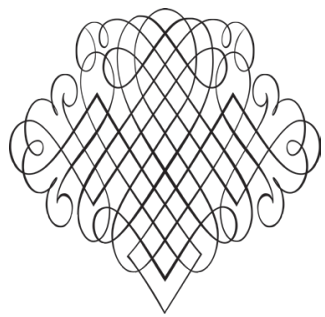

\title{
Розділ 4.
}

МУЗИЧНЕ ТА ПОЗАМУЗИЧНЕ

УДК $78.03: 783$ (438)

DOI 10.34064/khnum2-1812

Маринчак Г. В.

ORCID 0000-0002-2714-523X

Харківський національний університет мистецтв імені І. П. Котляревського, 61003, майдан Конституиії, 11/13, м. Харків, Україна

\section{Маріанська тема у музичному мистецтві: аспекти історичної та жанрової стилістики (на прикладі творчості К. Горського)}

АНОТАЦІЯ - Маринчак Г. В. Маріанська тема у музичному мистецтві: аспекти історичної та жанрової стилістики (на прикладі творчості К. Горського). - Образ Пресвятої Діви Марії надихав багатьох авторів християнського світу, але його трактування при загальній духовній єдності суттєво відрізнялися. Статтю присвячено вивченню основних параметрів втілення маріанської теми у музичному мистецтві з виділенням аспектів історичної та жанрової стилістики. Вибір теми пов'язаний із перспективою вивчення творчості харківського композитора польського походження К. Горського, який багато років (1880-1910) працював у Харкові і є одним із фундаторів його академічної музичної культури. У статті закладено методологічну базу для вивчення зразків відтворення маріанської теми у творчості цього автора, для чого здійснено аналіз відповідних дже- 
рел (богословських, музикознавчих та інших) з метою виведення жанрово-стилістичних класифікацій явища, що вивчається - конфесійної, власне жанрової, національної. Доведено, що, орієнтуючись на світовий досвід, К. Горський втілює всі ці моделі у трьох маріанських творах - канонічній церковній кантаті, більш масштабній кантаті світського змісту, акапельному хоровому концерті, залишаючись при цьому композитором із оригінальним та неповторним інтонаційним мисленням. — Ключові слова: образ Пресвятої Діви Марії, маріаністика, маріологія, маріанізм, маріанська тема в музиці, стилістичні аспекти відтворення маріанської теми, твори К. Горського на маріанську тему.

\section{АННОТАЦИЯ - Маринчак А. В. Марианская тема в музыкаль-} ном искусстве: аспекты исторической и жанровой стилистики (на примере творчества К. Горского). - Образ Пресвятой Девы Марии вдохновлял многих авторов христианского мира, однако его трактовки при общем духовном родстве существенно отличались. Статья посвящена изучению основных параметров воплощения марианской темы в музыкальном искусстве с выделением аспектов исторической и жанровой стилистики. Выбор темы связан с перспективой изучения творчества харьковского композитора польского происхождения К. Горского, который много лет (1880-1910) работал в Харькове и является одним из основателей его академической музыкальной культуры. В статье заложена методологическая база для изучения образцов претворения марианской темы в творчестве этого автора, для чего был осуществлён анализ соответствующих источников (богословских, музыковедческих и других) с целью выведения жанрово-стилистических классификаций изучаемого явления - конфессиональной, собственно жанровой, национальной. Доказано, что, ориентируясь на мировой опыт, К. Горский воплощает все эти модели в трёх марианских сочинениях - канонической церковной кантате, более масштабной кантате светского содержания, акапельном хоровом концерте, оставаясь при этом композитором с оригинальным и неповторимым интонационным мышлением. - Ключевые слова: образ Пресвятой Девы Марии, марианистика, мариология, марианизм, марианская тема в музыке, стилистические аспекты воплощения марианской темы, сочинения К. Горского на марианскую тему. 
ABSTRACT - Marynchak A. V. Marian Theme in Music: Aspects of History and Genre Stylistics (a Case Study of the Works by Konstanty Antoni Gorski).

- The objectives of the research. The article is devoted to the study of the main parameters of the Marian theme embodiment in the art of music, with highlighting the aspects of history and genre stylistics. It is noted that the choice of the topic is related to the study of the works by the Kharkiv composer of Polish origin Konstanty Antoni Gorski, who worked in Kharkiv for many years (1880-1910) and belongs to the founders of his academic musical culture. The article lays the methodological basis for studying interpretation of the Marian theme in the works by this author, for that the analysis of the relevant sources (theological, musicological, etc.) has been carried out to derive the genre-stylistic classifications for this phenomenon (confessional, genre, national classifications).

The results of the study. It is noted that the Marian theme in music can be classified as one of its central themes. This is due to the general ethical and natural content of the European music of the academic layer, which itself, as it is known, originated from the Church music and retained the features of high contemplation inherent in the cult genres, which determined the prospect line for the subsequent development of the Christian world music. The study emphasizes that the image of the Blessed Virgin Mary acts as a part and an important component of the New Testament, where two her main hypostases are presented. The Virgin Mary is honored and praised, firstly, as the Mother of the Son of God, who experienced suffering with him for the good of humanity, and secondly, as the intercessor and guardian of people who believe in her divine power and destiny.

Here, the two interpretations of the Blessed Virgin's image should be borne in mind, which are implemented at the confessional level - in the Catholic and Orthodox liturgical service. The whole branch of knowledge, called Mariology, is devoted to the study of these issues in the European theology and art history. The musical aspects of this field, presented in the monograph by O. Nemkova (2013), are closely related to religious teachings, as well as to their secular reflection at the level of the genre, style and stylistics of the musical works.

The musical interpretation of the Blessed Virgin's image, coming from Catholicism is based on the postulates of Her Divine destiny, which is reflected in the canonical texts in Latin, among which two main ones stand out - 
"Stabat Mater" and "Salve Regina". These texts are realized in the cantata genre, the basis of which is the style of da chiesa, that is, the concerto itself in the church that accompanies the service in honor of Virgin Mary. The latter takes place in such holidays: Conception of Mary by Her mother Anna, Nativity of Mary, Presentation of Mary, Annunciation, Dormition of the Mother of God.

The prayer "Ave Maria" is also very popular, and it has become for many European authors the basis of both applied religious and secular works, an example of which is the music of Early Baroque, Romanticism and Modern times. The secularization processes that began in the music of the Christian world on the turn of the Late Renaissance and Baroque (the watershed here is the 1600 year, the official year of the opera genre birth), called to life two groups of works on Marian themes: 1) the compositions nearby to the canonical original, as a rule, Latin texts (they were distributed among Catholics by religion and in Catholic countries); 2) the works modified, based on translations and free narrations of canonical texts given in the national languages and in suitable stylistics of one or another national culture (this is characteristic of Protestantism, as well as of Orthodoxy).

There is also a deep line of interpretation of the Blessed Virgin's image, personifying the eternal idea of motherhood and femininity, which is equally characteristic of many national musical cultures, in particular, the non-religious wave that manifested itself in Slavic music, first at the turn of the 19th 20th centuries, and then - during the last two decades of the 20th century. It is noted that Gorski, remaining a devout Catholic by the nature of his activity in such interfaith cultural center as Kharkiv in the late 19th - the first two decades of the 20th centuries, embodied in his work the traditions and demands coming from the Polish (Catholic) as well as the Ukrainian (Orthodox) and French and German (Lutheran, Protestant) musical cultures. On this basis, three of his opuses devoted to Virgin Mary arose: the Catholic cantata "Salve Regina" (for voice, violin and organ), the concerto-cantata in French "Salutation a la Sainte Vierge" (for soprano accompanied by choir, organ, string quintet and two French horns), and the choral concerto for the Orthodox mixed choir "Zriaszcze mia bezglasna" on the Old Slavonic text.

Each of these works is a special genre form, with which Gorski works as with a standard model equipped with a lexical layer of a certain musical stylistics, primarily national. The Polish song and romanza sources are traced in the first of the works, along with the obvious influence of the opera arias. 
In the cantata on the French text, echoes of not only opera scenes are heard, but also the elements of the programme music, story-telling, characteristic of French musical style. Finally, the Orthodox choral Concerto on the Old Slavonic text demonstrates the typical genre of the Ukrainian music - the large form intended for collective choral performance that was the equivalent of a symphony in the Western European musical culture.

Conclusion. It is proved that, guided by the world experience, Konstanty Antoni Gorski embodies all these models in three Marian works - the canonical church cantata, the larger-scale secular cantata, the a cappella choral concerto, while remaining a composer with original and unique intonational thinking. Gorski in these three compositions appears as a neoclassic, subordinating the original genres to his own creative intentions, which makes the music of these compositions comprehensible and accessible to a wide audience. It was that for the purpose to popularize the opuses by Gorski this article has been written. - Key words: the image of the Blessed Virgin Mary, Mariology, Marianism, Marian theme in music, stylistic aspects of the Marian theme realization, Konstanty Antoni Gorski, Gorski's works on the Marian theme.

Постановка проблеми. Образ Пресвятої Діви надихав багатьох авторів християнського світу, але трактування цього образу при загальній духовній єдності суттєво відрізнялися, насамперед, за ознаками конфесій - католицької та православної. Музичні твори 3 маріанської тематики в музиці Новітнього часу знайшли своє друге народження. Творчість такого майстра, як К. Горський, відобразила різні моделі втілення маріанської теми, що й визначило проблематику даного дослідження, зафіксовану у його назві.

Зв'язок 3 науковими та практичними завданнями. У науковому сенсі дана стаття продовжує низку досліджень щодо відтворення Богородицької тематики в музичному мистецтві. Оригінальним тут $€$ вибір аспектів іiі розгляду, серед яких вирізняються питання жанрової та національної стилістикі, що екстраполюються на творчість К. Горського-композитора, для якого маріанська тема була однією 3 провідних. У практичному плані представлена розвідка може бути 
корисною для вироблення методичних засад аналізу жанрово-стилістичних комплексів творів, які знаходяться в межах маріанської тематики.

Аналіз останніх публікацій. Незважаючи на актуальність досліджень маріанської теми в музиці, в сучасній музикознавчій літературі не так багато робіт, що їй безпосередньо присвячені. Вирізняються, перш за все, праці О. Немкової (2013; 2014), а також інших авторів найближчого до нас часу, де так чи інакше представлено вказану тематику (Аверинцев, С., 2004; Лосский, В., 1995; Бачинин, В., 2010, ін.). Разом із тим, маріанська тема відноситься до розряду «вічних». Отже, розгляд специфіки її відтворення в авторському стилі К. Горського виявляється актуальним.

Мета дослідження - окреслити методологічні засади втілення аспектів історичної та жанрової стилістики у творах на маріанську тему К. Горського.

Виклад основного матеріалу дослідження. Національно-ментальні витоки стилю К. Горського є невід'ємними від його католицького світогляду. Глибинні внутрішні зв'язки з образами Святого Письма пронизують цілий ряд його творів, причому не лише спеціалізованих богослужбових, але й світських за тематикою. Композиторська творчість К. Горського як представника європейського неокласицизму межі XIX-XX ст. відображувала в цілому сутність академічного музичного пласта - його «високий стиль», що мав тісний зв'язок із релігійними настановами. Музичні образи та вся система відображення дійсності у західноєвропейській музиці, починаючи від дискантистів школи Нотр-Дам XII ст. до додекафоністів XX-го, відбивали, за В. Конен (1978), тенденцію спорідненості «по прямій», тобто, виходили із загального тяжіння до етично-піднесеного та естетично-досконалого, духовно-гуманістичного у своїй сутності (с. 114).

Одним 3 найпопулярніших образів, що йдуть від сакральних текстів Біблії, в європейській культурі (особливо, в католицькому середовищі) був і залишається образ Діви Марії - символ чистоти, духовності, материнської любові, допомоги та спасіння. В європейському мистецтвознавстві, в тому числі і музикознавстві, сформувалася ціла дослідницька галузь під назвою «маріологія», культурологічні, ес- 
тетичні та світоглядні засади якої у різних історичних та національно-регіональних проявах сформульовані у дослідженнях О. Немкової $(2013,2014)$. Як зазначає дослідниця, маріологія як мистецтвознавча галузь виникла на базі впливу релігійних догматів християнства, насамперед, ідеології католицизму, на різні види мистецтва, де культ Богородиці - маріанізм - $є$ окремим і становить основу багатьох видів храмового богослужіння за участю музики. О. Немкова посилається на теологічні дослідження, де заснування маріології як релігійно-культурологічного феномена датується 1854 р., коли з'явилася булла Папи Пія IX «Ineffabilis Deus» (Боже невимовний), де міститься догмат про непорочне зачаття Пресвятої Діви Марії як Благодать Божу. Про це йдеться також у «Біблейській енциклопедії» (1991, стб. 102). Трактування постаті Богородиці в Новому Завіті відобразилося в маріології Нового часу у вигляді концепції сутності Діви Марії «... не лише як матері Христа, але й активної совиконавиці Божественного задуму» (там само). Розробка культа Богородиці в системі наукової теології та практики Богослужіння була досить тривалим процесом. Як відзначається в цитованому джерелі, для цього знадобилось впровадження додаткових догматів, головним серед яких було вчення про «тілесне вознесіння Богородиці, iї фізичне безсмертя» (там само, стб. 103). Особливо слід відзначити певну різницю, яка існує між догматами католицької та православної конфесій в осмисленні маріанізму. Спостерігається певний компроміс: «... ідеї маріанізму не заперечувалися східною церквою, хоча і не були закріплені догматично. B XVI-XVIII ст. під впливом посилення контактів із католиками маріанізм повсюдно поширився у південно-руській Церкві» (там само).

Характеризуючи маріанізм як релігійно-культурний феномен, що функціонує в християнському світі, слід мати на увазі і зв'язок образу Богоматері з іншими, поза-християнськими, уявленнями й віруваннями, міфами про богиню-матір: вавилонську Іштар, індійську Лакшмі, єгипетську Ісіду, давньослов'янську Берегиню і так далі. На підставі цих вірувань та їх відображення у генетичній пам'яті людства виникає цілий ряд спільних рис узагальнюючого змісту, які можна визначити через образ Богині-Матері. Він стає одним із знакових у мистецтві, в тому числі й в музиці, визначаючи характерні особливості свідомос- 
ті людини будь-якої епохи, вмотивовані ідеями «продовження життя», материнської любові, а також надійного «земного» захисту від «непередбачуваних небесних сил» (Немкова, О., 2013, с. 52).

Все це формує культ Богородиці та його відображення у різних видах мистецтва, який є культурологічною базою маріології як дослідницького дискурсу. Як надбання християнської культури, маріанізм віддзеркалював та являв людству новий образ Великої Матері 3 його неповторними рисами заступниці перед Богом, яка знає потреби і печалі людини. За О. Немковою, «... традиції вшанування Пресвятої Діви Марії закріплювались у народному середовищі вже на початку нашої ери завдяки тому, що Її вважали покровителькою народження дітей, сім'ї, продовження роду людського», звертаючись до Неї за допомогою у повсякденних побутових і господарчих справах (там само).

Дослідники-маріаністи, зокрема, О. Немкова у згаданих вище роботах, а також автори праць про музичну культуру Середньовіччя, Ренесансу та Бароко - М. Лобанова (1994), Ю. Евдокимова (1989), Т. Дубравська (1996) - підкреслюють, що зі ствердженням християнства значною мірою змінилися і естетичні ідеали, котрі панували в античному світі, почалося формування нового розуміння ролі мистецтва в суспільстві, вираженого узагальненим поняттям «Art» (єдність наукового та художнього у пізнанні світу, розуміння людини як Творіння Божого). Зокрема, згідно середньовічним уявленням про музику, головним їі призначенням було «очищення від скверни пристрастей», щоб «вивільнена душа могла рухатися шляхом благочестя» (за О. Немковою, 2013, с. 53). Саме тому сюжети й образи Біблії та Євангелія стають для музики не лише провідними, але й фактично єдиними, а висвітлення образу Матері Божої у цьому контексті вирізняється не лише кількістю зразків, але й особливою затребуваністю у найширшому народному середовищі, що відкривало шлях до подальшої секуляризації музичного мистецтва, в якому від сакрального прикладного призначення зберігалася лише висока етична ідея.

Як розкривається з теологічних та мистецтвознавчих джерел, побожне ставлення до земного образу Матері Спасителя сформувалося не відразу. Цей образ, навіть при його близькості, «зрозумілості» 
простій людині, залишався все ж приналежним до Божественної історії, у якихось рисах - «незбагненним» (Немкова, О., 2013, с. 54). Ореол таємничості, сакральності завжди супроводжував мистецькі втілення образу Пресвятої Діви, чому посприяла й церква, для якої важливо було зберігати дистанцію між нею та паствою. В якості єднальної ланки тут виступали, за О. Немковою, «Богородичні піснеспіви», які слід вважати основою всіх подальших втілень музичного маріанізму (там само). Як свідчать відомі на теперішній час музичні пам'ятники перших століть нашої ери, піснеспіви на честь Мадонни стали практикуватися ще у V ст. Вже тоді сформувалися дві лінії їхньої трактовки - католицька (Рим) та православна (Візантія); при цьому «... у Візантії культ Богородиці оформився раніше і набув форм більш величних і пишних, ніж у Римі того часу» (там само). Задля розуміння сутності впливу цих співів авторка наведених слів додає, що «... почуття поклоніння, розчулення, побожного захвату перед світлим ликом Богоматері однаково близькі і католику, і православному християнину» (там само).

Проте ці «сакральні переживання» знайшли у східному та західному культах різне «звучання»: «Для середньовічних католицьких маріанських співів з часом стануть все більш характерними високий емоційний тон релігійного висловлювання, високий ступінь зосередженості на висловлюваному в адресу Мадонни почутті. В православних же піснеспівах і проповідях, при збереженні традиції осмислення подвигу та святості Богородиці на загально-символічному рівні, чітко позначено також прагнення до поглибленої психологізації в окресленні центрального образу» (там само).

О. Немкова підтверджує цю дихотомію цілим рядом прикладів. Зокрема, ще в IV ст. у «Проповіді на Благовіщеня» Св. Іоанна Златоуста Марія втілює собою «храм, що одушевляється», «розумний кивот», «обиталисько, рівне небу та землі», «лествицю небесну», по якій спускається Господь, «обитель, гідну Логосу». Все це, за О. Немковою (2013), не просто епітети, котрими наділяє Пресвяту Богородицю візантійський гімнограф; «... в них - образне і ємне відтворення розуміння Її місії у Божественному визначенні спасіння провинного людського роду» (с. 30). У наведених висловлюван- 
нях Св. Іоанна Златоуста Пресвята Діва (особливо у зв’язку з темою Благовіщеня) уособлює собою храм, дім, обитель, тобто певне «вмістилище», яке «оберігається» і «захищається». Останнє є, на думку О. Немкової, важливим мотивом, який отримає яскраве продовження в художній культурі Древньої Русі як спадкоємиці візантійських традицій (там само).

Католицьке ментальне сприйняття образу Богородиці не є таким екзальтованим, як у гімнотворців Візантії та Православної Церкви, яка вийшла з іiі надр. Тут спостерігається більш виважений і навіть канонізований підхід до музично-поетичного трактування образу Богородиці у піснеспівах, зразками яких є григоріанські хорали. На відміну від східних гімнів, вони відрізнялись більшою аскетичністю, а також тісним зв'язком із мовною інтонацією, яка не виходила за межі наспівної речитації в монодіях вузького інтервального діапазону. Проте згодом, як зазначає О. Немкова (2013), музично-католицьке відображення Богородиці починає набувати рис деякої екзальтації, яка формувалася не без впливів Східної церкви (с. 217). Далі авторка зазначає, що після Ефесського собору традиції культу Богородиці увійшли до фази активного формування: якщо у Свангелії згадки про Діву Марію є досить лаконічними, то вже з другої половини V ст. в теологічній науці складається більш-менш повна Її біографія, формується коло головних Богородицьких свят, а вже в VII ст. у Візантії створюється перший Акафист Пресвятої Богородиці (там само).

Формування циклу Богородицьких свят значною мірою стимулювало їхні музичні втілення та оформлення. Це були, зокрема, богослужіння, присвячені таким подіям, як Зачаття Марії іiі матір'ю Анною, Різдво Марії, Введення в храм, Благовіщеня, Успіння Богоматері. Як зазначають теологи (Библейская энциклопедия, 1991), культурологи та мистецтвознавці, зокрема, В. Бачінін (2010; Бачинин, В., н. д.), кожне 3 цих свят вже у VII-VIII ст. було достатньо докладно описано у церковній літературі і до нашого часу зберігає свою канонізовану роль, котра визначає і функцію музичної складової в окремому Богослужбовому чині. Зазначимо, слідом за О. Немковою (2013), що канонізовані історії та події з життя Діви Марії на землі та на небесах доповнювалися численними народними переказами та апо- 
крифами, в яких відображувалось відношення віруючих до цього святого образу, який набув значення «антропологічного лейтмотиву» (Лосский, В., 1995, с. 70) християнського вчення.

Аналогічні процеси естетизації образу Пресвятої Діви з наданням йому особливого теургічного змісту спостерігалися і в художній літературі, зокрема, епохи Романтизму, свідченням чому можуть бути заключні слова 3 «Фауста» Й. Гете (надаємо їх в оригінальному перекладі Б. Пастернака) (Гете, Й.-В., 1975, с. 509]:
Все быстротечное
Символ, сравненье.
Цель бесконечная
Здесь - в достиженье.
Здесь - заповеданность
Истины всей.
Вечная женственность
Тянет нас к ней.

Якщо у літературознавстві естетика і поетика богородицької / маріанської теми відображена досить розлого (насамперед, це робота С. Аверинцева (2004), то музикознавство досі знаходиться у розкритті цієї теми в рамках «галузевого відособлення», що диференціюється на релігієзнавство, естетику, культурологію, історію та теорію різних видів мистецтв (Немкова, О., 2014, с. 4).

Як зазначає С. Аверинцев (2004), « ... якщо Христос - боголюдина по єству, то кожен християнин потенційно є боголюдиною по благодаті, і перша в цьому ряду - Діва Марія, в особі якої людська природа разом 3 найбільш тілесними аспектами підноситься понад безтілесну духовність ангелів» (с. 433) (курсив автора). Дослідник далі відзначає, що образ Марії - це одна з головних ниток, що зв’язує священні тексти Старого та Нового Завітів, але всі події в Її долі та масштаб «звучання» теми Пресвятої Діви у християнському мистецтві, без сумніву, визначено тим, що Вона - Матір Спасителя (там само). У зв'язку з цим, як головні в художній (зокрема, музичній) маріаністиці виділяються та відтворюються такі сюжетні лінії та епі- 
зоди життя Богородиці, в яких Ї̈ї доля поєднуються 3 долею Сина: Благовіщеня, Голгофа, Успіння. В їхньому музичному втіленні виділяються, за О. Немковою (2014), два «полюси», що створюють своєрідну смислову «арку». Однією кульмінаційною точкою стає смисловий концентрат образу Пресвятої Діви - католицька молитва «Ave Maria», заснована на сюжеті Ії̈ заручення із Святим Духом (православний варіант - «Богородище, Діво, радуйся»). Іншою - сповнене скорботи оповідання, узагальнене католицькою секвенцією «Stabat Mater», де міститься драматична розповідь про страждання Марії у Хреста Спасителя і охоплюється все Його земне життя (с. 26).

Щодо виникнення молитви «Ave Maria» і епічної поеми-оповідання «Stabat Mater», то вони з'явились, судячи з музичної історіографії, відповідно, в XII і XIII ст. Одночасно ці піснеспіви стали означати більш-менш сталі жанрові форми музичної маріаністики, чому передував досить довгий шлях формування піснеспівного глосарія у вигляді хоралів-монодій (католицька традиція) та гімнів (візантійська православна традиція). Будучи ключовими жанрами, вказані різновиди богородицької / маріанської тематики в музиці з часом знаходили різні відтворення, серед яких виділяються, перш за все, власне богослужбове, прикладне, та секуляризоване, світське, за функцією концертне. В такій диференціації відображується головна дихотомія музичної жанровості взагалі - розподіл всієї системи жанрів на дві основні групи - «прикладні» жанри, ніби вбудовані до позамузичних явищ, та «автономні», власне музичні (за О. Соколовим, 1997). Зазначимо також, що головним чинником жанру є його функція - життєва та художня, що дає підстави виділяти у кожній жанровій системі «однину та множину» (за С. Назайкінським, 2003), «одночасність» та «неодночасність» становлення (за К. Дальхаузом - Dahlhaus, С., 1973), «зміст» та «стиль» (за А. Сохором, 1968), «зовнішнє» та «внутрішнє» (за Л. Шаповаловою, 1984).

Філософсько-естетична та художня багатозначність маріанської теми в мистецтві визначає іiі особливу жанрову специфіку. По-перше, це - постійна присутність основоположної «старої» традиції (константи жанру), по-друге - тяжіння до взаємодії мистецтв; по-третє орієнтація на моножанровість, яка, проте, не виключає існування жан- 
рових «гібридів». Функція узагальнення, яка традиційно відноситься до жанру в музиці, діє, таким чином, неоднозначно. Вона завжди корегується стильовими чинниками, в результаті чого постає як комплекс. Отже, маріанська тема може породжувати і реально породжує досить велику кількість стилістичних втілень, у яких на перший план виступають фактори стилетворення, насамперед, індивідуального. Слід враховувати й інші стилістичні «прикмети», перш за все, як вже відзначалося, національні, історичні (періоди створення зразків), конфесійні (приналежність автора до тієї чи іншої гілки християнства), суто організаційні (наявність виконавських колективів, окремих солістів, залів, концертних майданчиків тощо). Тому власне звернення до маріанської теми та вибір відповідного жанру в двох його «функціях» - художній та життєвій - є прерогативою автора маріанського твору, який бере на себе відповідальність за адекватність втілення цієї сакральної теми.

Саме такими відповідальними якостями відзначається творчість у даному жанрі К. Горського - католицького автора, який, проте, мислить власні відтворення образу Пресвятої Діви не лише як архетипічні, але й як індивідуальні, почуттєві, здатні викликати у слухачів різноманітні та глибокі емоційні враження. Важливу роль відіграють не лише жанрові форми, але й вибір вербальних текстів, зокрема, їхня мова. У К. Горського це - латинь, французька, старослов'янська, що відображено у трьох названих нижче музичних зразках. Окрім цього, дуже важливим $\epsilon$ і виконавський склад. У тих випадках, коли акцент робиться на сольній вокальній складовій, виникає камерний, ніби інтимний, психологічно деталізований варіант втілення маріанської теми. У творах, де сольно-вокальна складова $є$ лише рядоположною хоровій чи оркестровій, виникає образ іншого змісту, який можна охарактеризувати як носій соборності, ідейної єдності, що розкриває діяння Богородиці як заступниці роду людського перед Спасителем.

Всі ці варіанти втілення Богородицької теми представлено у творчості К. Горського. Перший з них - католицький, заснований на канонічному латинському тексті в кантаті «Salve, Regina» для сопрано, скрипки та органу; другий варіант - це світська кантата на французький текст «Salutation a la Sainte Vierge» для сопрано у супроводі хору, 
органу, струнного квінтету та двох валторн; третій варіант - хоровий концерт для православного змішаного хору «Зряще мя, безгласна»на старослов' янський текст. Всі ці твори потребують окремого вивчення, що автор даної статті й планує здійснити в майбутньому.

Висновки. Таким чином, в рамках даного дослідження відзначимо, що, незважаючи на всі відмінності у трактуваннях, маріанська тема у музиці завжди залишається константною у своєму духовному та етико-естетичному змісті, що відображується через відповідні жанрово-стилістичні моделі. К. Горський відпрацьовує різні варіанти цих моделей, вибудовуючи свій власний «музично-маріанський» стиль, у якому поєднується риси різних національних стилістик, насамперед, польської, а також французької та української традицій втілення образу Богородиці. Це і визначає в сукупності характерні прикмети авторського стилю композитора, для якого маріанська тема була однією $з$ провідних.

Перспектива подальших досліджень заявленої теми полягають у можливості екстраполяції методологічних засад iї розгляду на рівень аналізу конкретних творів, зокрема, згаданих у даній статті трьох зразків втілення маріанської теми К. Горським. Видається за необхідне віднайти стилістичні закономірності відтворення образу Пресвятої Діви у різних нахилах - ментально-національному, мовно-вербальному, мовно-музичному, персонально-авторському, враховуючи, поряд 3 цим, інтегруюче значення постаті К. Горського як композитора-неокласика межі XIX-XX ст., чия творчість формувалася під впливом реалій музичного життя тодішнього Харкова як осередку, де перетиналися елементи різних національних музичних культур, типових для Слобожанщини.

\section{ЛІТЕРАТУРА}

Аверинцев, С. С. (2004). Византийский культурный тип и православная духовность: Некоторые наблюдения. В кн.: Аверинцев С. С. Поэтика ранневизантийской литературы, сс. 426-444. Санкт-Петербург: Азбука-классика.

Бачинин, В. А. (2010, 11 авг.). Художественно-эстетическая мариология. Газета Протестант. URL: http:/www.gazetaprotestant.ru/2010/08/ hudozhestvenno-esteticheskaya-mariologiya 
Бачинин, В. А. (н. д.). Интертекст мировой цивилизации: христианская геосоциальная девиантология (методологические проблемы). Отримано 20.05.2019 3 http://www.narcom.ru/publ/info/634

Библейская энииклопедия (1991). Москва: Терра, 602.

Гёте, И.-В. (1975). Фауст. Трагедия. Собрание сочинений. (Тт. 1-10). T. 2. Б. Пастернак (Пер. с нем.). Москва: Художественная литература, 510.

Дубравская, Т. (1996). Музыка эпохи Возрождения (XVI век). История полифонии, вып. 2Б. Москва: Музыка, 441.

Евдокимова, Ю. (1989). Музыка эпохи Возрождения. История полифонии, вып. 2А. Москва: Музыка, 413.

Конен, В. Дж. (1978). Третий пласт. Советская музыка, 5, 113-118.

Лобанова, М. (1994). Западноевропейское музыкальное барокко: проблемы эстетики и поэтики. Москва: Музыка, 318.

Лосский, В. Н. (1995). Всесвятая. В кн.: В. Н. Лосский. По образу и подобию. В. А. Рещикова (Пер. с фр.), сс. 69-75. Москва: Издательство Свято-Владимирского братства.

Назайкинский, Е. В. (2003). Стиль и жанр в музыке. Москва: ВЛАДОС, 248.

Немкова, О. В. (2013). Образ Богоматери в европейском музыкальном искусстве: константы и метаморфозы. Тамбов: Издательский дом ТГУ им. Г. Р. Державина, 205.

Немкова, О. В. (2014). Образ Богоматери в западноевропейской художественной культуре: инвариант и эволючионные модификации. (Автореф. дис. ... Д-ра искусствоведения). Саратовская государственная консерватория (академия) имени Л. В. Собинова. Саратов, 45.

Соколов, О. В. (1977). К проблеме типологии музыкальных жанров. В сб.: Проблемы музыки ХХ века. Цендровский В. М. и др. (Редкол.), сс. 12-57. Горький: Волго-Вятское книжное издательство.

Сохор, А. (1968). Эстетическая природа жанра в музыке. Москва: Музыка, 104.

Шаповалова, Л. В. (1984). О взаимодействии внутренней и внешней формы в исторической эволючии музыкальной жанровости. (Автореф. дис. ... канд искусствоведения). Киевская государственная консерватория им. П. И. Чайковского. Киев, 23. 
Dahlhaus, C. (1973). Zur Problematik der musikalischen Gattungen im 19. Jahrhundert. In Wulf Arlt u. a. (Hrsg.). Gattungen der Music in Einzeldarstellungen: Gedenkschrift Leo Schrade. Folge 1, S. 840-895. Bern; Munchen: Francke Verlag.

\section{REFERENCES}

Averintsev, S. S. (2004). Vizantiyskiy kulturnyy tip i pravoslavnaya dukhovnost: Nekotorye nablyudeniya [Byzantine Cultural Type and Orthodox Spirituality: Some Observations]. In Averintsev, S. S. Poetika rannevizantiyskoy literaturyPoetics of Early Byzantine Literature, pp. 426-444. St. Petersburg: Azbukaklassika [in Russian].

Bachinin, V. A. (2010, August 11). Khudozhestvenno-esteticheskaya mariologiya [Art and Aesthetic Mariology]. Gazeta Protestant - Newspaper Protestant. Retrieved from http://www.gazetaprotestant.ru/2010/08/hudozhestvennoesteticheskaya-mariologiya [in Russian].

Bachinin, V.A. (n. d.). Intertekst mirovoy tsivilizatsii: khristianskaya geosotsialnaya deviantologiya (metodologicheskie problemy) [Intertext of World Civilization: Christian Geosocial Deviantology (Methodological Problems)]. Retrieved 2019, May 20 from http://www.narcom.ru/publ/info/634 [in Russian].

Bibleyskaya entsiklopediya [Biblical Encyclopedia] (1991). Moscow: Terra, 602 [in Russian].

Dahlhaus, C. (1973) Zur Problematik der musikalischen Gattungen im 19. Jahrhundert [The problem of musical genres in the 19th century]. In Wulf Arlt, etc. (Eds.). Gattungen der Music in Einzeldarstellungen: Gedenkschrift Leo Schrade - Genres of music in individual representations: commemorative scripture by Leo Schrade. Episode 1, pp. 840-895. Bern; Munich: Francke Verlag [in German].

Dubravskaya, T. (1996). Muzyka epokhi Vozrozhdeniya (XVI vek) [Music of the Renaissance $\left(16^{\text {th }}\right.$ Century)]. Istoriya polifonii - History of Polyphony, iss. $2 \mathrm{~B}$. Moscow: Muzyka, 441 [in Russian].

Goethe, J. W. (1975). Faust. Tragediya [Faust. Tragedy]. Sobranie sochineniy Collected works. (Vols. 1-10). Vol. 2. Pasternak, B. (Transl. from German). Moscow: Khudozhestvennaya literatura, 510 [in Russian].

Konen, V. Dzh. (1978). Tretiy plast [Third Layer]. Sovetskaya muzyka Soviet Music, 5, 113-118 [in Russian]. 
Lobanova, M. (1994). Zapadnoevropeyskoe muzykalnoe barokko: problemy estetiki i poetiki [Western European Musical Baroque: Problems of Aesthetics and Poetics]. Moscow: Muzyka, 318 [in Russian].

Losskiy, V. N. (1995). Vsesvyataya [All-Holy]. In V. N. Losskiy. Po obrazu $i$ podobiyu - In the image and likeness. V. A. Reshchikova (Transl. from French), pp. 69-75. Moscow: Izdatelstvo Svyato-Vladimirskogo bratstva, [in Russian].

Nazaykinskiy, Ye. V. (2003). Stil i zhanr v muzyke [Style and Genre in Music]. Moscow: VLADOS, 248 [in Russian].

Nemkova, O. V. (2013). Obraz Bogomateri v evropeyskom muzykalnom iskusstve: konstanty i metamorfozy [The Image of the Mother of God in European Music: Constants and Metamorphoses]. Tambov: Izdatelskiy dom TGU im. G. R. Derzhavina, 205 [in Russian].

Nemkova, O. V. (2014). Obraz Bogomateri $v$ zapadnoevropeyskoy khudozhestvennoy kulture: invariant $i$ evolyutsionnye modifikatsii [The Image of the Mother of God in Western European Art Culture: Invariant and Evolutionary Modifications]. (Extended abstract of Art History Doctoral Thesis). Saratov State Conservatory (Academy) named after L. V. Sobinov. Saratov, 45 [in Russian].

Shapovalova, L. V. (1984). O vzaimodeystvii vnutrenney $i$ vneshney formy $v$ istoricheskoy evolyutsii muzykalnoy zhanrovosti [On the Interaction of Internal and External Forms in the Historical Evolution of Musical Genre]. (Extended abstract of Candidate's thesis). Kiev State Conservatory named after P. I. Tchaikovsky. Kiev, 23 [in Russian].

Sokhor, A. (1968). Esteticheskaya priroda zhanra v muzyke [The Aesthetic Nature of the Genre in Music]. Moscow: Muzyka, 104 [in Russian].

Sokolov, O. V. (1977). K probleme tipologii muzykalnykh zhanrov [On the Issue of Typology of Musical Genres]. In Problemy muzyki XX veka-Problems of music of the twentieth century. Tsendrovskiy V. M., et al. (Eds.), pp. 12-57. Gorkiy: Volgo-Vyatskoe knizhnoe izdatelstvo [in Russian].

Yevdokimova, Yu. (1989). Muzyka epokhi Vozrozhdeniya [Music of the Renaissance]. Istoriya polifonii - History of Polyphony, iss. 2A. Moscow: Muzyka, 413 [in Russian].

Стаття надійшла до редакиії 9.09.2019 р. 